\title{
Distributional notes on some Nosodendridae (Coleoptera) - XXII. A new species of Nosodendron (Nosodendron) from India
}

\author{
JIř́i HÁVA
}

\author{
Forestry and Game Management Research Institute, \\ Strnady 136, CZ-252 02 Praha 5 - Zbraslav, Czech Republic \\ e-mail: jh.dermestidae@volny.cz
} HÁva, J: Distributional notes on some Nosodendridae (Coleoptera) - XXII. A new species of Nosodendron
(Nosodendron) from India.

Abstract: A new species, Nosodendron (Nosodendron) nathani sp. nov., from India, the Kerala State, is described, illustrated and compared with a similar species, Nosodendron (N.) disjectum Champion, 1923.

Keywords: taxonomy, description, new species, Coleoptera, Nosodendridae, Nosodendron, India.

\section{Introduction}

The small family Nosodendridae (Coleoptera) recently contains 2 genera and 104 species (Háva 2019, 2020). The family Nosodendridae was placed to Derodontoidea by Bouchard et al. (2011), McKenna et al. (2019) placed the family Nosodendridae to Nosodendroidea. A new species of the genus Nosodendron from the Kerala State belonging to the nominotypical subgenus is described here.

\section{Material and methods}

Locality labels of the material mentioned are cited in the original version. Specimens of the presently described species are provided with red, printed labels with the text as follows: „HOLOTYPE [or PARATYPE] Nosodendron (N.) nathani sp. nov. Jiří Háva det. 2020".

Type material is deposited in the following collection: JHAC Jiři Háva, Private Entomological Laboratory and Collection, Prague-west, Czech Republic. 


\section{Results}

Nosodendron (Nosodendron) nathani sp. nov.

(Fig. 1)

Type material. Holotype (ふ): „South India, Kerala State, Trivandrum, Poommundi

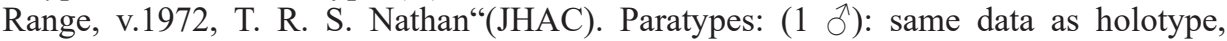
(JHAC).

Description. Male. Measurements (in $\mathrm{mm}$ ): total length 4.2-4.3; maximum elytral width 2.8-2.9. Body very convex and broad. Cuticle black, matt. Head finely, but clearly punctate, with very short yellow setae. Eyes large, visible from above. Antennae brown, with eleven antennomeres, antennal club with three antennomeres, with yellow setae. Mentum with small punctures, with long yellow setae. Pronotum punctate as head; with very short yellow setae. Pronotal anterior angle without groove. Scutellum triangular, finely punctate. Elytra finely punctate, with tufts of setae forming rows. Near scutellum, each elytron with one short stria consisting of large punctures. Epipleuron black. Mesosternum finely and regularly punctate. Metasternum without longitudinal carina, with large punctures. Legs black, tibiae and femora finely punctate, with long yellow setation and dark brown thorns. Visible abdominal ventrites dark brown. Longitudinal striation of base of abdominal ventrites very short, with punctures. Male genitalia as in Fig. 1.

\section{Female. Unknown.}

Differential diagnosis. The new species belongs to the nominotypical subgenus of the genus Nosodendron. The subgenus contains four species; the new species is very similar to Nosodendron $(N$.$) disjectum Champion, 1923, but differs from it by the structure of$ male genitalia.

Etymology. Patronymic, dedicated to the collector of the new species T. R. S. Nathan.

Nosodendron disjectum Champion, 1923

Material examined: S India, Tamil Nadu state, Nilgiri hills, $10 \mathrm{~km} \mathrm{SW} \mathrm{of} \mathrm{Manjoor,}$ $76^{\circ} 35^{\prime} \mathrm{E} 11^{\circ} 12^{\prime} \mathrm{N}$, Thiasola reserved forest, near Carrington estate, ca $2100 \mathrm{~m}, 14-19$. vi.1999, Z. Kejval \& M. Trýzna lgt., (2 ふぇ゙) : (JHAC).

Distribution. Species is described from Nilgiri Hills; India: Tamil Nadu: Nilgiri Hills. 

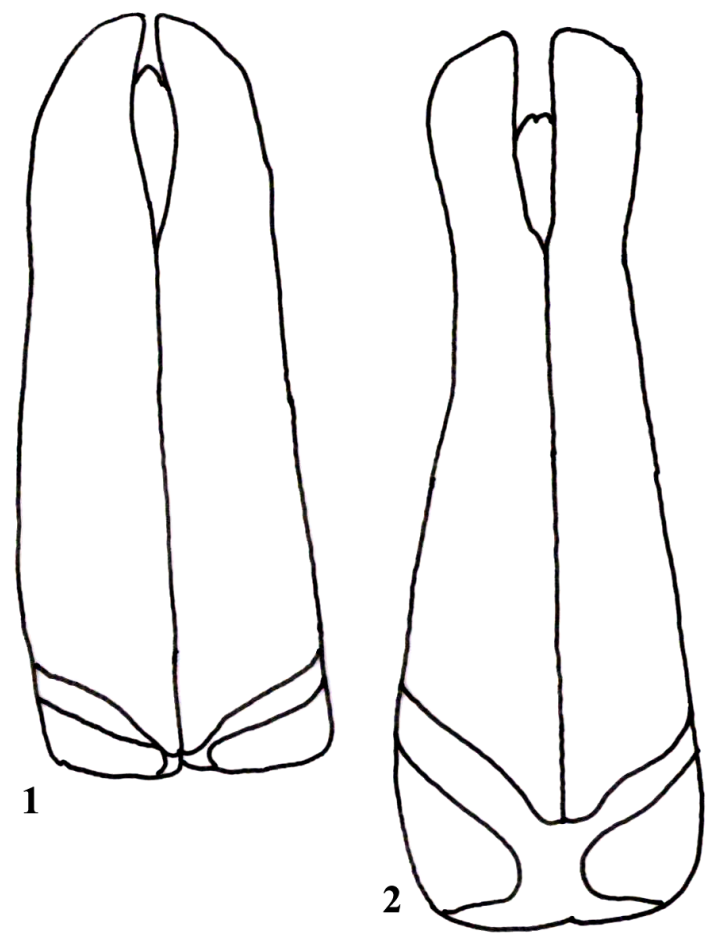

Figs. 1-2: Nosodendron $(N$.$) nathani sp. nov.: 1- male genitalia,$ Nosodendron ( $N$.) disjectum Champion, 1923: 2- male genitalia

Checklist of Nosodendron s. str.

Family Nosodendridae Erichson, 1846

Genus Nosodendron Latreille, 1804

Nosodendron asiaticum Lewis, 1889

Distribution: Japan, Russia: Kuril Is.

Nosodendron californicum Horn, 1874

Distribution: Canada: British Columbia, USA.

Nosodendron fasciculare (Olivier, 1790)

Distribution: Europe, Caucasus.

Nosodendron disjectum Champion, 1923

Distribution: India: Tamil Nadu: Nilgiri Hills.

Nosodendron nathani sp. nov.

Distribution: India: Kerala State. 


\section{Acknowledgements}

I am indebted very much to Miloslav Rakovič (Czech Republic) for a revision of the English manuscript. The paper was supported by the Ministry of Agriculture of the Czech Republic, institutional support MZE-RO0118.

\section{References}

Bouchard P., Bousquet Y., Davies A. E., Alonso-Zarazaga M. A., Lawrence J. F., Lyal Ch. H. C., Newton A. F., Reid Ch. A. M., Schmitt M., Slipinski S. A. \& Smith A. B. T. 2011: Family-group names in Coleoptera (Insecta). - ZooKeys 88: 1-972. DOI: https://doi.org/10.3897/zookeys.88.807

Háva J. 2019: Distributional notes on some Nosodendridae (Coleoptera) - XX. Description of a new species from the Philippines. - Euroasian Entomological Journal 18(6): 409-411. DOI: https://doi.org/10.15298 / euroasentj.18.6.08

Háva J. 2020: Distributional notes on some Nosodendridae (Coleoptera) - XXI. A new Nosodendron species from Malaysia. - Linzer Biologische Beitrage 52(1): (in press) DOI: http://doi.org/10.5281/zenodo. 4526777

McKenna D. D., Shin S., Ahrens D., Balke M., Beza-Beza C., Clarke D. J., Donath A., Escalona H. E., Friedrich F., Letsch H., Liu S., Maddison D., Mayer Ch., Misof B., Murin P. J., Niehuis O., Peters R. S., Podsiadlowski L., Pohl H., Scully E. D., Yan E. V., Zhou X., Ślipiński A. \& Beutel R. G. 2019 : The evolution and genomic basis of beetle diversity. - PNAS 116(49): 24729-24737. DOI: https://doi. org/10.1073/pnas.1909655116 